Artikel Penelitian

\title{
Perancangan Dan Pengujian Penjejak Cahaya Matahari Untuk Modul Surya Dengan Sistem Microcontroller Arduino Uno ATMega 328
}

\author{
Iskandar R., David Alif Utama, Lovely Son \\ Jurusan Teknik Mesin, Fakultas Teknik, Universitas Andalas, Padang
}

INFORMASI ARTIKEL

\section{Sejarah Artikel:}

Diterima Redaksi: 08 Februari 2018

Revisi Akhir: 22 Maret 2018

Diterbitkan Online: 26 April 2018

\section{KATA KUNCI}

Solar modules

Solar radiation intensity

Solar tracker

Arduino uno

KORESPONDENSI

E-mail: iskandar@ft.unand.ac.id

\begin{abstract}
A B S T R A C T
Device that can convert sunlight into electrical energy is called solar modules. The solar modules are available in the market only for a static condition, while the light intensity always changes based on the incidence angle of the sun. To make the solar modules more optimal, it is always perpendicular to the direction of the sun so it is needed to use solar tracker device. Solar tracker device is commercially sold at relatively high prices. To solve this problem, it will be designed a relatively lower price one. The design is also made to overcome the obstacles of previous studies and fulfill the wishes of prospective consumers. After the design is done, it is obtained solar tracker for solar modules with a control system microcontroller arduino uno ATMega 328. In this research, the testing parameters consist of; the angle of solar modules, solar radiation intensity, the output voltage of the solar modules and battery charging voltage when the load is given. From the research having been done, solar modules with solar tracker have about $0.99 \%$ angle deviation of the ideal angle value, can increase about $65.68 \mathrm{~W} / \mathrm{m}^{2}$ solar intensity and about 0.22 Volts battery voltage with a fixed load.
\end{abstract}

\section{PENDAHULUAN}

Modul surya adalah alat yang dapat mengubah cahaya matahari menjadi energi listrik. Modul surya terdiri dari sel-sel surya yang disusun secara seri dan paralel untuk mendapatkan energi listrik yang sesuai dengan kebutuhan penggunanya. Sel surya dibuat dari lapisan sel silikon yang di-doping dengan dua unsur kimia yang berbeda. Silikon yang didoping dengan unsur boron membentuk silikon tipe-p dan silikon yang di-doping dengan unsur fosfor membentuk silikon tipe-n. Apabila dikenai cahaya matahari, pada silikon tipe-n akan terjadi penumpukan elektron dan pada silikon tipep akan terjadi kekurangan elektron. Lapisan ini dihubungkan oleh sebuah sirkuit sehingga elektron (yaitu arus) akan mengalir melalui sirkuit tersebut.
Pada bagian atas dan bagian bawah modul surya terdapat logam kontak yang akan mengalirkan listrik dari modul surya menuju beban [1].

Modul surya yang dijual di pasaran secara umum hanya untuk kondisi statis, sedangkan intensitas cahaya matahari selalu berubah berdasarkan sudut datang matahari. Dengan kondisi statis tersebut, intensitas radiasi matahari langsung yang dapat diserap oleh modul surya menjadi tidak optimal. Radiasi matahari langsung dapat diserap secara optimal jika posisi matahari berada pada posisi tegak lurus terhadap modul surya. Alat yang dapat digunakan untuk meningkatkan kapasitas penyerapan dari modul surya adalah penjejak cahaya yang dihubungkan dengan motor untuk menggerakkan modul surya, sehingga matahari 
akan berada pada posisi tegak lurus terhadap modul surya. Pada tahun 2007, Adi Kurniawan telah membuat penjejak cahaya yaitu mekanisme solar tracker pada kolektor parabolik. Penjejak cahaya tersebut dapat bergerak dalam beberapa saat dan kemudian berhenti dikarenakan tidak cukupnya daya untuk menggerakkan sistem [2]. Melihat permasalahan ini dilakukan pengkajian kembali bagaimana merancang daya yang dapat menggerakkan mekanisme penjejak cahaya dengan menggunakan sebuah program pengendali.

\section{KAJIAN PUSTAKA}

\subsection{Sel Surya}

Sel surya atau sel fotovoltaik yang paling umum terbuat dari silikon kristal tunggal. Sebuah atom silikon dalam kisi kristal menyerap foton dari radiasi matahari, dan jika energi foton cukup tinggi, maka elektron dari kulit terluar atom akan terbebas. Proses ini membentuk sepasang lubang elektron, satu lubang menutupi kekurangan elektron dan satunya lagi keluar dari struktur kristal. Ini biasanya menghilang secara spontan, yang mana elektron dapat bergabung kembali dengan lubang. Proses penggabungan kembali dapat dikurangi dengan membentuk penghalang di dalam sel. Bagian-bagian dari sel surya ditunjukkan pada Gambar 1.

Pada satu sisi penghalang silikon dicampur dengan boron membentuk silikon $\mathrm{p}$, yang memiliki kekurangan elektron di kulit terluarnya, dan pada satu sisinya lagi dicampur dengan fosfor membentuk silikon $\mathrm{n}$, yang memiliki kelebihan elektron pada kulit terluarnya. Penghalang menghambat elektron bermigrasi secara bebas, sehingga terjadi penumpukan elektron pada lapisan

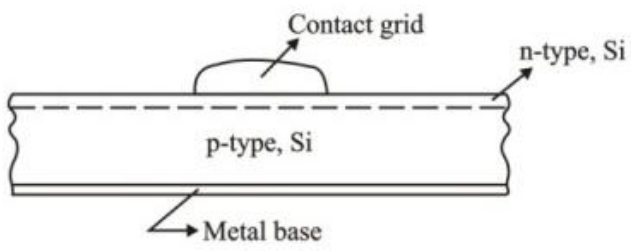

Gambar 1. Bagian-bagian dari sel surya [1] silikon $\mathrm{n}$ dan kekurangan elektron pada silikon $\mathrm{p}$. Jika lapisan ini dihubungkan oleh sebuah sirkuit, elektron (yaitu arus) akan mengalir melalui sirkuit tersebut. Dengan demikian elektron dari silikon $n$ dapat mengalir melalui sirkuit ke silikon p. Kontak listrik terbuat dari logam dasar terdapat pada bagian bawah sel surya dan logam kisi pada lapisan atas sel surya [1].

\subsection{Penjejak Cahaya Sebelumnya}

Adi Kurniawan dari Jurusan Teknik Mesin Universitas Andalas telah membuat mekanisme penjejak cahaya matahari (solar tracker) untuk kolektor surya parabolik pada tahun 2007. Rancangan menggunakan bandul yang dihubungkan dengan roda gigi untuk menggerakkan kolektor surya parabolik [2]. Mekanisme solar tracker untuk kolektor surya parabolik Adi Kurniawan ditunjukkan pada Gambar 2.

Agar mekanisme dapat bekerja, maka diberi gaya awalan pada bandul, namun bandul hanya bergerak untuk beberapa saat dan kemudian berhenti. Sehingga harus diberi lagi gaya awalan agar sistem dapat kembali bekerja. Adi Kurniawan menyimpulkan hal ini dapat terjadi karena gesekan antara roda gigi yang mengakibatkan daya tidak cukup untuk menggerakkan sistem, sehingga pada roda gigi harus diberi pelumas dan perlu penambahan sumber daya sistem [2].

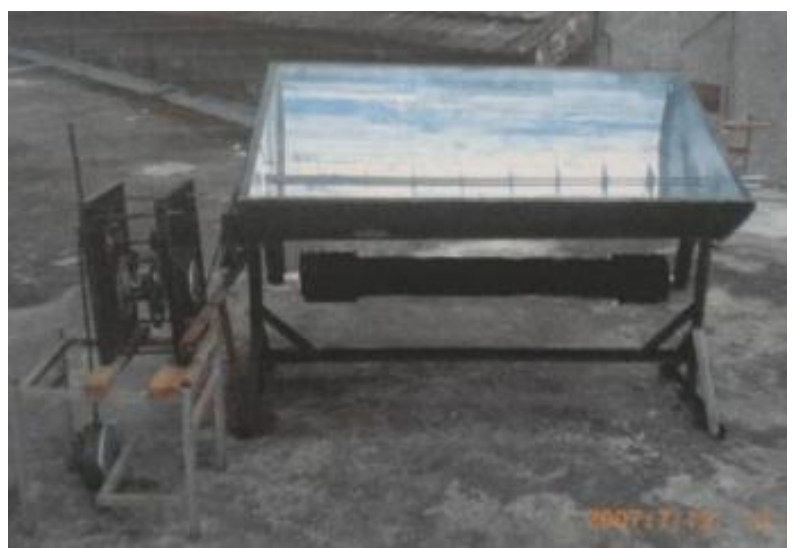

Gambar 2. Mekanisme solar tracker untuk kolektor surya parabolik Adi Kurniawan [2] 


\subsection{Sistem Kontrol Lup Terbuka}

Sistem kontrol lup terbuka yaitu sistem kontrol yang keluarannya tidak mempengaruhi aksi pengontrolan. Pada sistem kontrol lup terbuka, keluaran tidak diukur atau diumpan-balikkan untuk dibandingkan dengan masukkan. Hubungan masukkan keluaran sistem kontrol lup terbuka ditunjukkan pada Gambar 3.

Setiap masukkan pada sistem kontrol lup terbuka terdapat suatu kondisi operasi yang tetap. Sistem kontrol lup terbuka harus dikalibrasi dengan hatihati dan kalibrasi harus dijaga agar sistem dapat berfungsi dengan baik. Ketika terdapat gangguan, sistem kontrol lup terbuka tidak dapat bekerja seperti yang diinginkan. Sistem kontrol lup terbuka hanya dapat digunakan jika hubungan antara

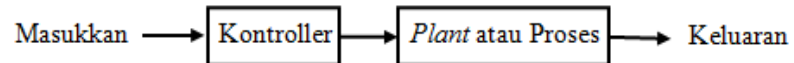

Gambar 3. Hubungan masukkan keluaran sistem kontrol lup terbuka [3] dan keluaran diketahui dan tidak terdapat gangguan internal dan eksternal. Setiap sistem kontrol yang bekerja pada basis waktu merupakan sistem kontrol lup terbuka [3].

\section{METODOLOGI}

Perancangan yang dilakukan dalam rangka pembuatan alat pada penelitian ini menggunakan strategi desain seperti pengumbulan masalah, pengelompokan masalah, solusi alternatif dan pemlihan alternatif. Dan detelah pengumpulan masalah dari kendala-kendala pada penelitian sebelumnya dan keinginan konsumen, maka pengelompokan masalah dengan orientasi permintaan konsumen ditampilkan pada Gambar 4 dan house quality-nya ditampilkan pada Tabel 1.

Berdasarkan weighted objective didapatkan solusi yang digunakan dalam perancangan dan pembuatan penjejak cahaya matahari yang ditunjukkan pada Tabel 2.

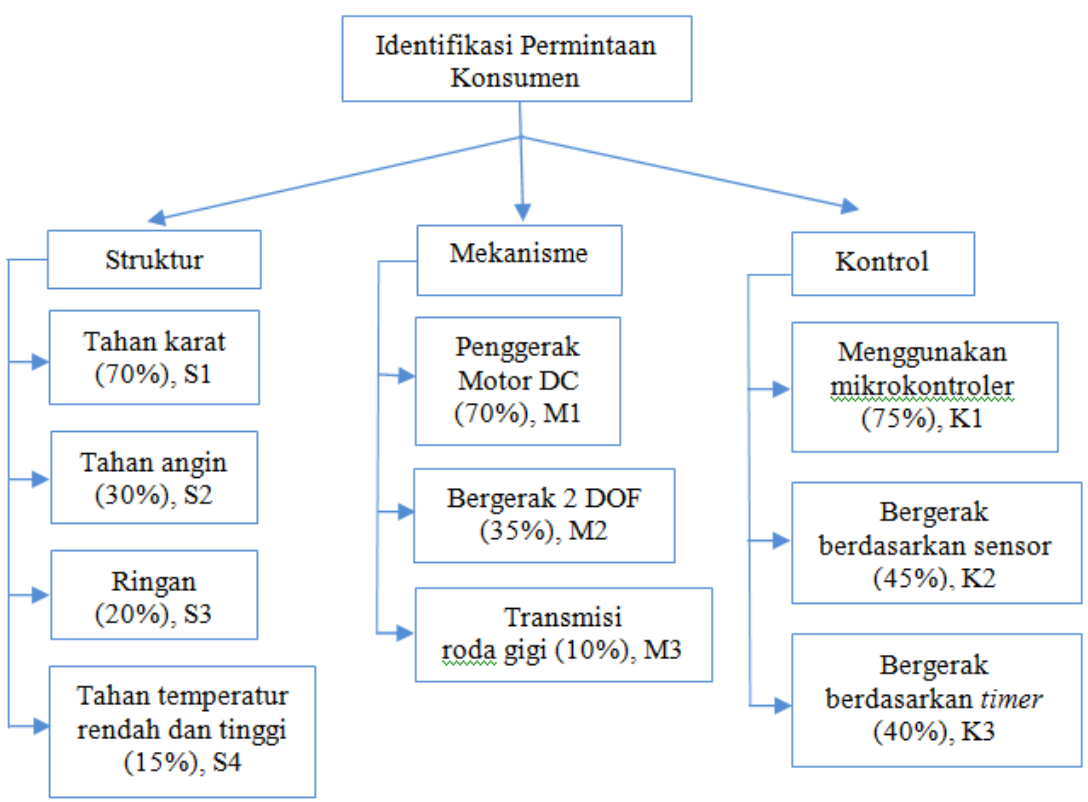

Gambar 4. Identifikasi permintaan konsumen

Pada house quality terdapat keterangan sebagai berikut:

EC : Engineering characteristics

CA : Customer attributes

CAI : Customer attributes importance

ECI : Engineering characteristic importance

$\mathrm{U} \quad$ : Units 
Tabel 1. House quality

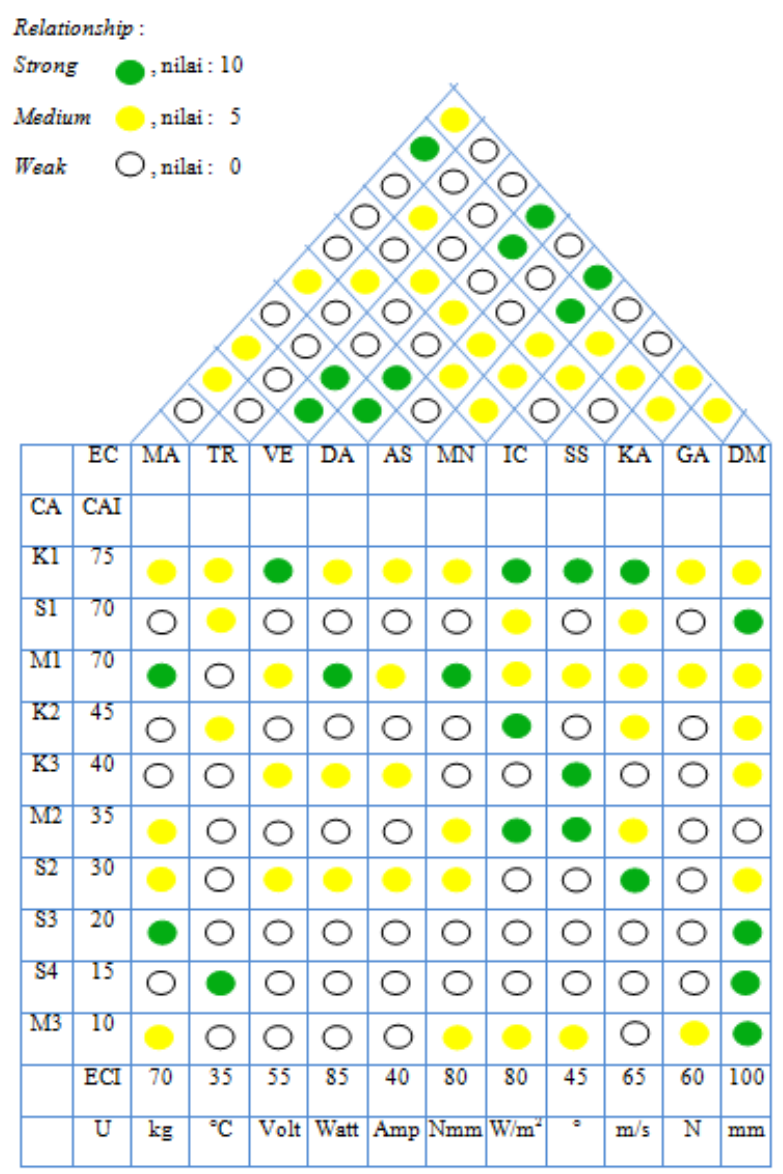

Dimana :

$\begin{array}{llllll}\text { MA } & =\text { Massa } & \text { TR } & =\text { Temperatur } & \text { VE } & =\text { Voltage } \\ \text { DA } & \text { = Daya } & \text { AS } & \text { = Arus } & \text { MN } & =\text { Momen } \\ \text { IC } & =\text { Intensitas cahaya } & \text { SS } & \text { = Sudut slope } & \text { GA } & =\text { Gaya } \\ \text { KA } & =\text { Kecepatan angin } & \text { DM } & =\text { Dimensi / Material } & & \end{array}$

Tabel 2. Solusi yang digunakan pada perancangan dan pembuatan penjejak cahaya matahari Customer attributes (CA) Solusi

Mikrokontroler (K1)

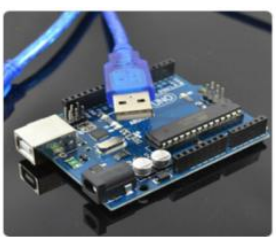

Arduino Uno ATMega 328

Tahan Karat (S1)

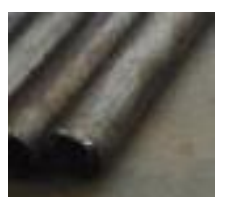

Besi silinder hollow 


Bergerak berdasarkan timer (K3)

\subsection{Sistem Kendali}

Sistem kendali yang digunakan pada penjejak cahaya matahari adalah sistem kontrol lup terbuka. Sistem kontrol lup terbuka penjejak cahaya matahari ditunjukkan pada Gambar 5.

\subsection{Alat Ukur yang Digunakan}

Pada penelitian ini digunakan beberapa alat ukur antara lain yaitu Light Meter, Magnetic Torpedo Level, Digital DC Volt Amp Meter (multimeter). 


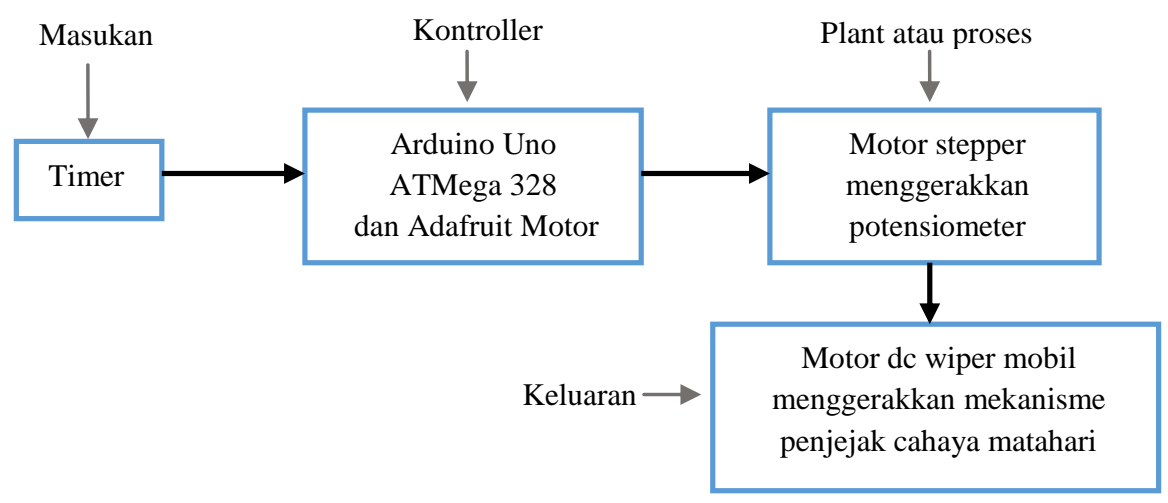

Gambar 5. Contoh Penulisan Caption Pada Gambar

\subsection{Prosedur Pengujian}

\subsubsection{Prosedur pengujian sudut kemiringan modul surya}

(1) Penjejak cahaya dihidupkan dengan cara mengonkan saklar yang terdapat pada panel kontrol. Kontrol yang digunakan yaitu mode kontrol lup terbuka tanpa timer; (2) Posisi modul surya diatur pada sudut $45^{\circ}$, lalu kontrol dipindahkan ke mode kontrol lup terbuka dengan timer. Timer dihidupkan dengan meng-onkan saklar pada panel control; (3) Pengujian dimulai pada pukul 09.0016.00 WIB. Pada setiap kenaikan waktu 30 menit dilakukan pengukuran kemiringan sudut modul surya menggunakan magnetic torpedo level; (4) Setelah pengukuran pada pukul $16.00 \mathrm{WIB}$, timer di-off-kan dan kontrol dikembalikan pada mode kontrol lup terbuka tanpa timer. Modul surya di posisikan pada arah terbit matahari dan semua saklar di-off-kan untuk mematikan sistem kontrol penjejak cahaya matahari.

\subsubsection{Prosedur uji karakteristik modul surya}

Prosedur uji karakteristik modul surya $60 \mathrm{Wp}$ dengan menggunakan beban fan brusless $12 \mathrm{~V}$ adalah sebagai berikut: (1) Alat ukur disiapkan seperti magnetic torpedo level, light meter, multimeter; (2) Alat ukur intensitas cahaya matahari ditempatkan di atas modul surya; (3) Setiap kenaikan waktu 15 menit, dilakukan pengukuran terhadap intensitas cahaya matahari, tegangan $\mathrm{V}_{\mathrm{mpp}}$; (4) Pengukuran dilakukan pada kondisi statik dan pada kondisi menggunakan penjejak cahaya matahari.

\subsubsection{Prosedur uji pengecasan baterai dengan beban tetap}

Prosedur uji pengecasan baterai $12 \mathrm{~V} 50 \mathrm{~A}$ dengan menggunakan modul surya $60 \mathrm{Wp}$ dan fan $12 \mathrm{~V}$ sebagai beban tetap adalah sebagai berikut: (1) Baterai $12 \mathrm{~V} 50 \mathrm{~A}$, fan $12 \mathrm{~V}$ dc dan solar charger controller dipasang pada rangkaian instalasi uji; (2) Alat ukur intensitas cahaya matahari ditempatkan di atas modul surya saat dilakukan pengambilan data; (3) Setiap kenaikan waktu 5 menit dilakukan pengukuran terhadap intensitas cahaya matahari, tegangan baterai saat pengecasan; (4) Pengujian dilakukan pada kondisi statik dan pada kondisi dengan menggunakan penjejak cahaya matahari. 


\section{HASIL DAN PEMBAHASAN}

\subsection{Hasil Perancangan}

Dari rancangan yang telah dilakukan didapat hasil rancangan penjejak cahaya matahari sebagai berikut: kontrol menggunakan microcontroller aruduino uno ATMega 328, struktur menggunakan besi silinder hollow dengan ukuran diameter 3,1 $\mathrm{cm}$ dan tebal $1 \mathrm{~mm}$, mekanisme 1 DOF dengan motor dc wiper, timer yang digunakan yaitu timer delay 2B3D, pengguat menggunakan kawat seling dengan ukuran diameter $4 \mathrm{~mm}$., transmisi timing belt dan poros yang digunakan yaitu poros besi berdiameter $20 \mathrm{~mm}$. Gambar hasil perancangan penjejak cahaya

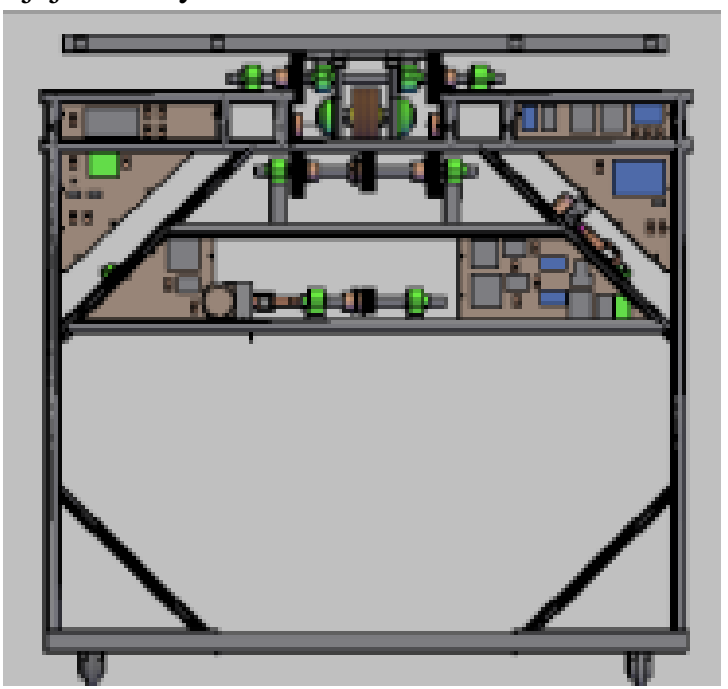

Gambar 6. Hasil perancangan penjejak cahaya matahari

matahari dapat dilihat pada Gambar 6 dan hasil pembuatan dapat dilihat pada Gambar 7.
Dari Gambar 7 dapat dilihat baterai 12V 45A yang digunakan sebagai penggerak motor-motor instalasi. Baterai tersebut diisi ulang menggunakan modul surya $10 \mathrm{Wp}$ sebanyak dua buah yang diletakkan di sebelah modul uji $60 \mathrm{Wp}$.

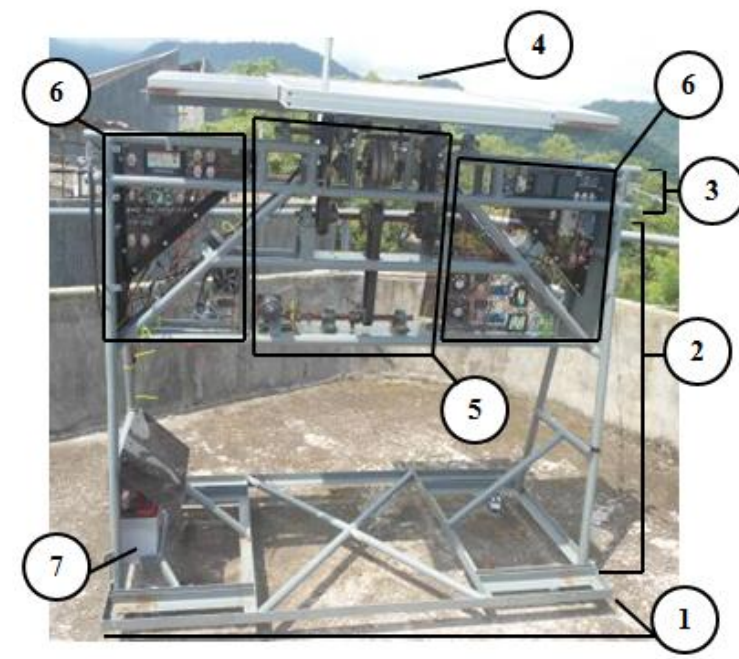

Keterangan Gambar:

1. Struktur penjejak cahaya matahari bagian dasar.

2. Struktur penjejak cahaya matahari bagian tengah.

3. Struktur penjejak cahaya matahari bagian atas.

4. Modul surya.

5. Mekanisme pengerak penjejak cahaya matahari.

6. Panel kontrol penjejak cahaya matahari.

7. Baterai $12 \mathrm{~V} 45 \mathrm{~A}$.

Gambar 7. Penjejak cahaya matahari untuk modul surya dengan microcontroller arduino uno 


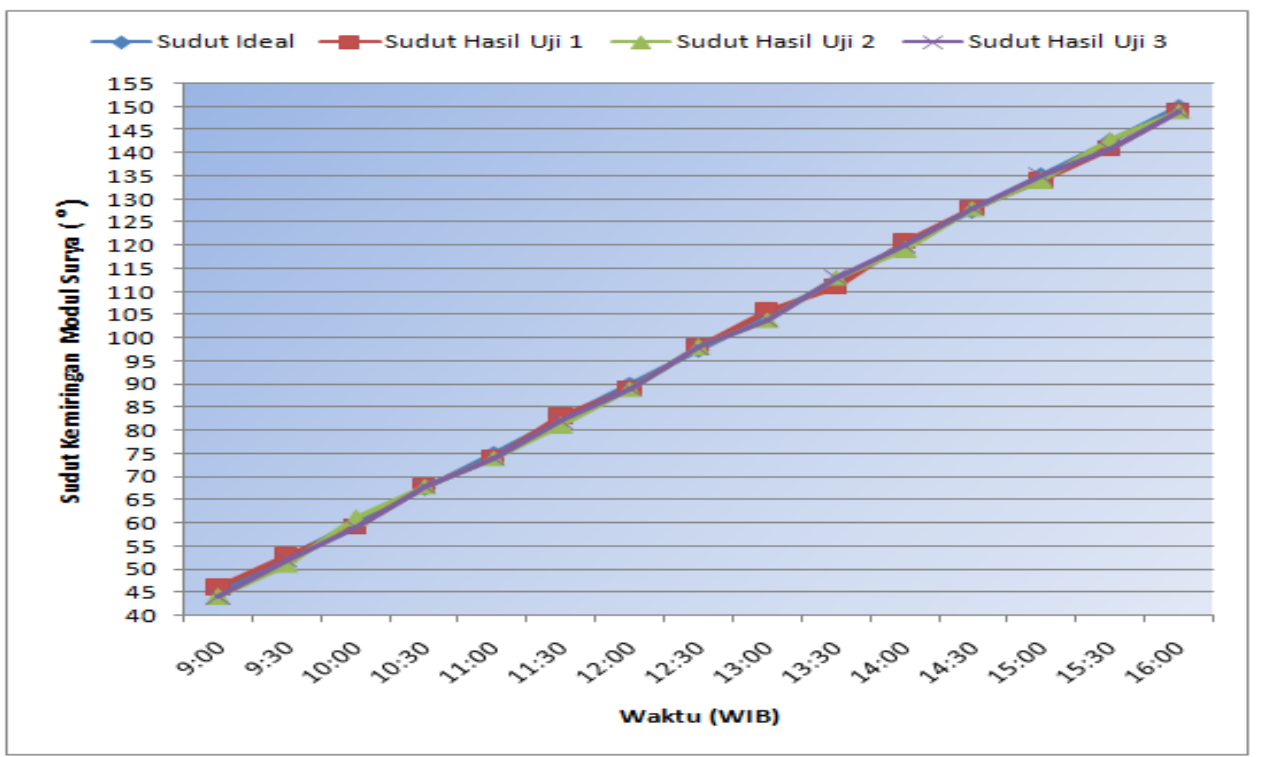

Gambar 8. Hasil pengujian sudut kemiringan modul surya dengan penjejak cahaya matahari

\subsection{Uji Sudut Modul Surya}

Dari hasil pengujian penjejak cahaya matahari dengan menggabungkan sistem timer delay, microcontroller arduino uno dan motor $d c$ controller, didapatkan hasil bahwa penjejak cahaya matahari telah dapat berfungsi dengan cukup baik. Penjejak cahaya matahari dapat bergerak mulai dari pukul 09.00 WIB sampai pada pukul 16.00 WIB. Grafik hasil pengujian penjejak cahaya matahari ditunjukkan pada Gambar 8.

Dari grafik hasil pengujian penjejak cahaya matahari dapat dilihat sudut hasil uji yang dilakukan sebanyak tiga kali (tiga hari) pengujian yaitu sudut uji 1, sudut uji 2 dan sudut uji 3 pada penjejak cahaya matahari memiliki nilai yang telah mendekati dengan sudut ideal kemiringan modul surya terhadap posisi matahari. Dari tiga kali pengujian diperoleh penyimpangan sudut rata-rata sebesar $0,99 \%$ dari nilai sudut ideal.

\subsection{Uji Karakteristik Modul Surya}

Pengujian karakteristik modul surya dilakukan untuk kondisi statik dan dengan menggunakan penjejak cahaya. Sudut kemiringan modul surya pada kondisi statik yaitu $75^{\circ}$ terhadap bidang vertikal. Beban pada uji karakteristik modul surya menggunakan fan brusless $12 \mathrm{~V}$ dc. Pengujian dimulai pada pukul 09.00-16.00 WIB dengan pengambilan data pada setiap kenaikan waktu 15 menit. Grafik mengenai intensitas cahaya matahari terhadap waktu ditunjukkan pada Gambar 9.

Perbedaan intensitas cahaya matahari tampak pada pukul 09.00 WIB sampai pada pukul 09.45 WIB, dengan menggunakan penjejak cahaya matahari dapat meningkatkan penerimaan intensitas cahaya matahari sebesar $114,55 \mathrm{~W} / \mathrm{m}^{2}$. Perbedaan intensitas cahaya matahari tidak begitu besar terjadi pada pukul 10.00 WIB sampai pada pukul 12.00 WIB. Hal ini dikarenakan pada saat tersebut sudut kemiringan modul surya pada kondisi statik dan dengan menggunakan penjejak cahaya matahari tidak jauh berbeda. Perbedaan intensitas cahaya matahari kembali tampak pada pukul 12.15 sampai pada pukul 16.00 WIB. Dari pengujian yang dilakukan dapat dikatakan bahwa modul surya dengan menggunakan penjejak cahaya matahari dapat meningkatkan penerimaan intensitas cahaya matahari rata-rata sebesar 65,68 $\mathrm{W} / \mathrm{m}^{2}$ dari pukul 09.00-16.00 WIB. 


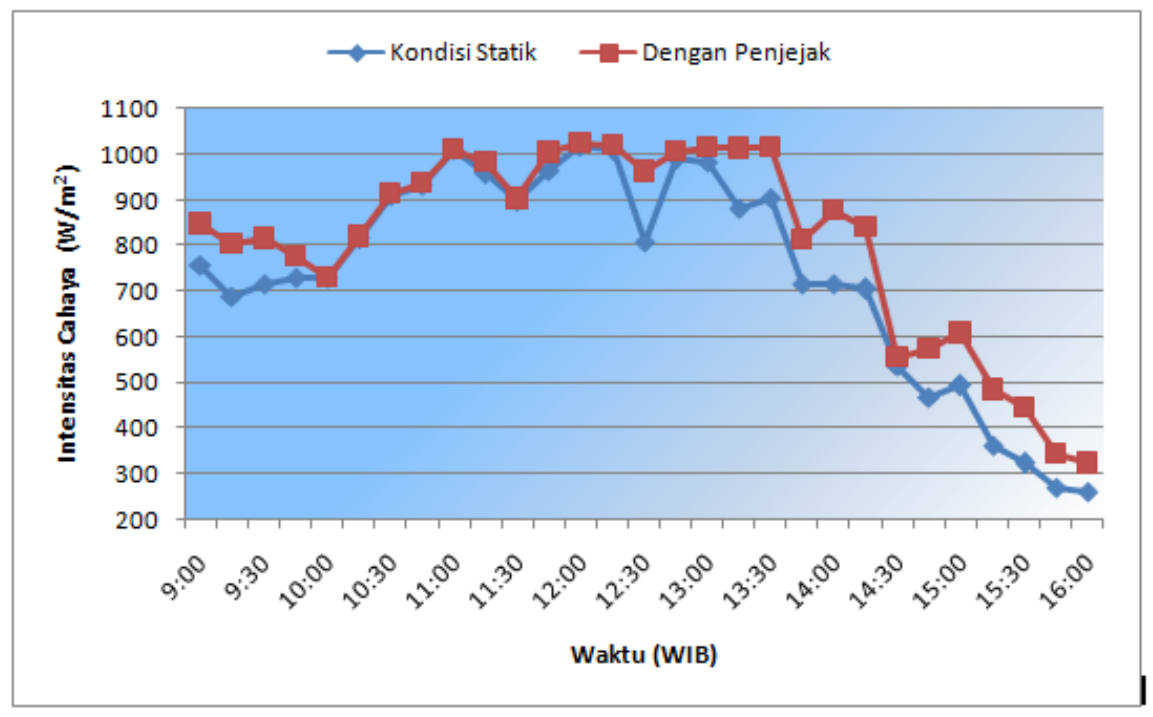

Gambar 9. Pengaruh waktu terhadap intensitas cahaya matahari

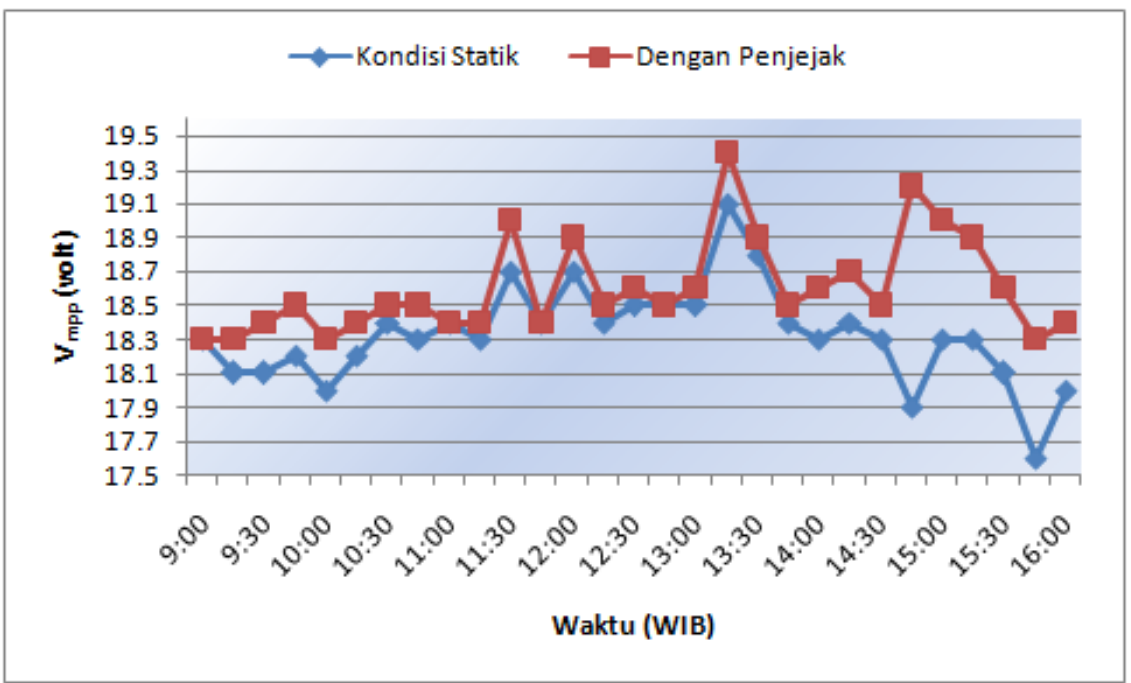

Gambar 10. Pengaruh waktu terhadap tegangan $\mathrm{V}_{\text {mpp }}$ modul surya

Sedangkan tegangan $\mathrm{V}_{\text {mpp }}$ dari modul surya dari waktu pengujian ditunjukkan pada Gambar 10. Tegangan $\mathrm{V}_{\text {mpp }}$ pada kondisi dengan menggunakan penjejak cahaya matahari lebih besar dibandingan dengan kondisi statik terlihat jelas pada pukul 09.15 WIB sampai pada pukul 10.15 WIB dan pada pukul 14.00 WIB sampai pada pukul 16.00 WIB. Hal ini disebabkan oleh lebih optimalnya penangkapan sinar matahari oleh modul surya dengan menggunakan penjejak cahaya. Dari seluruh waktu pengujian modul surya terjadi peningkatkan rata-rata sebesar sebesar 0,3 volt.

\subsection{Uji Pengecasan Modul Surya}

Pengecasan dilakukan dari modul surya 60 watt pada baterai $12 \mathrm{~V}$ 50A dengan memberikan beban tetap fan $12 \mathrm{~V}$ pada baterai yang dicas. Hasil pengujian tegangan baterai ditampilkan pada Gambar 11. 
Dari Gambar 11 dapat dilihat bahwa perbedaan tegangan baterai yang lebih besar terjadi pada pukul 11.15 WIB sampai dengan pukul 16.00 WIB. Tegangan baterai maksimum pada kondisi statik yaitu sebesar 13,3 volt dan tegangan baterai maksimum pada kondisi dengan menggunakan penjejak cahaya matahari yaitu sebesar 13,3 volt. Tegangan baterai minimum pada kondisi statik yaitu sebesar 12,7 volt dan tegangan baterai minimum pada kondisi dengan menggunakan penjejak cahaya matahari yaitu sebesar 12,9 volt. Dengan menggunakan penjejak cahaya matahari dapat meningkatkan tegangan baterai rata-rata sebesar 0,22 volt.

\section{KESIMPULAN}

Dari penelitian yang telah dilakukan dapat diambil beberapa kesimpulan sebagai berikut: (1) Sistem kontrol dengan mikrokontroler Arduino Uno ATMega 328 dapat diterapkan sebagai pengendali penjejak cahaya; (2) Penjejak cahaya matahari untuk modul surya mempunyai penyimpangan sudut rata-rata sebesar $0,99 \%$ dari nilai sudut ideal dan dapat meningkatkan penerimaan intensitas cahaya matahari rata-rata sebesar $65,68 \mathrm{~W} / \mathrm{m}^{2} ;(3)$ Dengan menggunakan penjejak cahaya matahari dapat meningkatkan tegangan baterai rata-rata sebesar 0,22 volt dengan pembebanan tetap pada baterai.

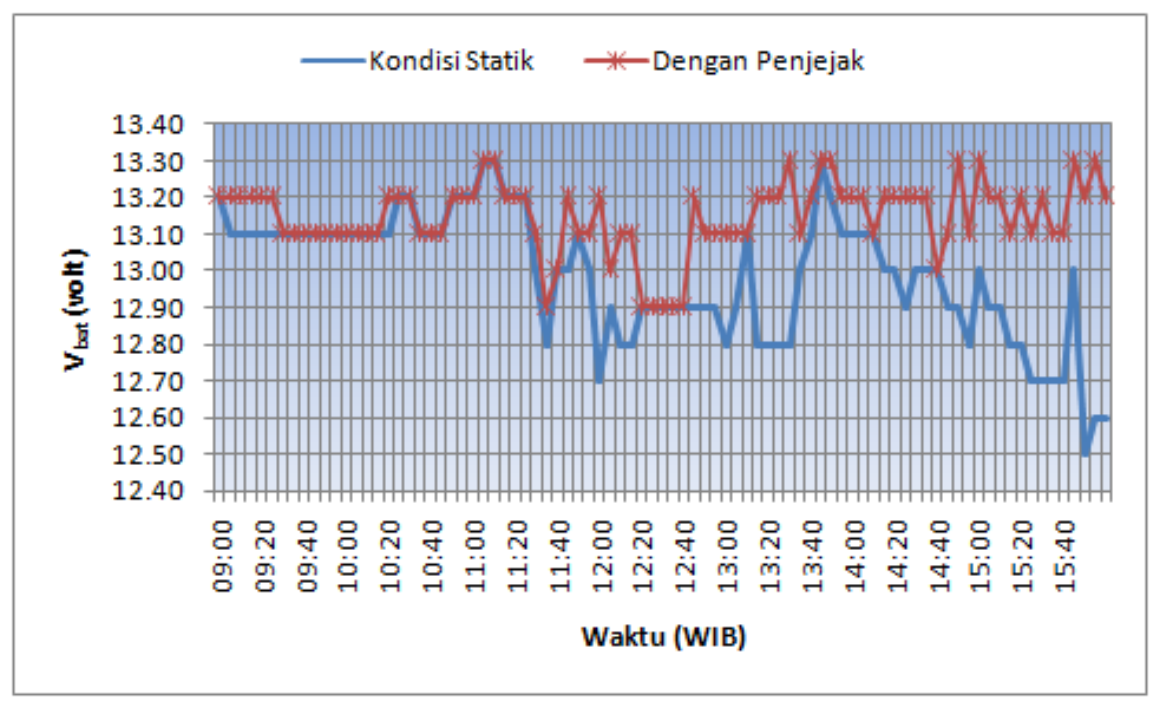

Gambar 11. Perubahan tegangan baterai pengecasan akibat beban tetap pada baterai

\section{DAFTAR PUSTAKA}

[1] A.J. Dufffi and A.W. Beckman, "Solar Engineering of Thermal Process", Third Edition, Jhon Wiley \& Sons, Inc., New Jersey, 2006.

[2] A. Kurniawan, "Mekanisme Solar Tracker Untuk Kolektor Parabolik; Perancangan dan Pengujian", Jurusan Teknik Mesin Fakultas Teknik Universitas Andalas, 2007.

[3] K. Ogata, "Teknik Kontrol automatik (Sistem Pengaturan)”, Jilid 1, Erlangga, 1993.

[4] http://xinpengsolar.en.made-inchina.com/product/sXLxpBMAZPVv/ChinaLinkage-Single-Axis-Tracking-System-for-
Solar-Power-Station.html, Dikutip pada tanggal 13 Desember 2014.

[5] W. Ismanto, "Perancangan dan simulasi sistem kontrol posisi pada panel surya dengan menggunakan metode fuzzy sliding mode control", Jurusan Matematika Institut Teknologi Sepuluh Nopember Surabaya, 2010.

[6] W. Saputra, "Rancang bangun solar tracking system untuk mengoptimalkan penyerapan energi matahari pada solar cell", Program Studi Teknik Elektro Universitas Indonesia, 2008. 